\title{
Self-secularisation as challenge to the church
}

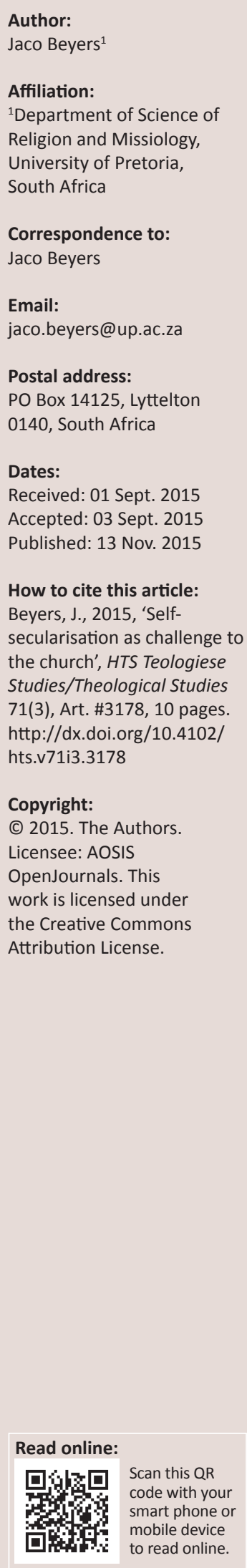

The concept of self-secularisation has been identified by Wolfgang Huber, bishop of the German Evangelische Kirche in Deutschland (EKD), when he reflected on the context of the church in Germany. Self-secularisation however, is a worldwide phenomenon with effects in South Africa as well. After discussing the origin of the concept and its interpretations, the author tries to identify instances of self-secularisation within especially the Afrikaansspeaking churches, although not limited to them, in South Africa. The theological jargon comes under scrutiny, civil religion, the pluralistic society within which the church exists, the effect of emotionalism, the commercialisation of the church, the role of mass media and the phenomenon of infotainment, rationalisation and a lack of ethics are some of the elements identified and discussed. Finally the author attempts a correction by indicating what the church ought to do in order to counter the effects of self-secularisation.

\section{Introduction}

Issues of faith need to be put on the table again, the church needs to engage in social issues and find new ways of expressing neighbourly love. Dr Christo van der Merwe has for some time been on the forefront of church development in South Africa. With this article a contribution is made to celebrate his efforts in guiding the church through difficult times.

That the institutional church is experiencing deep trouble and problems worldwide is evident. The decline in numbers (members and financial income) is an indication of a deep-lying threat to the existence of the church. Of course there are many factors to blame for the condition the church is in currently. The effects of secularisation for one cannot be underestimated (cf. Beyers 2014). The main areas of guilt that are to be assumed: external and internal factors. This research is more concerned with the internal elements contributing to the demise of the church. The actions, words and decisions emanating from the church may contribute to the deplorable state the church is in. Bishop Wolfgang Huber (1999) has identified the concept of self-secularisation as a contributing factor to the gradual decline of the importance of the church in Germany. To what extent is self-secularisation part of the problem in Protestant communities in South Africa? That is the question this article wants to address.

In order to understand secularisation a synchronic analysis of the word 'secular' might be necessary. The origin of the term 'secular' comes from the Latin saeculum (Calhoun, Juergensmeyer \& Van Antwerpen 2011:11). Apparently the term saeculum fell within the temporal domain of understanding (Casanova 2011:56). A specific period of time, a millennium: ten saecula, was meant. According to a Christian interpretation the term saeculum came to denote temporary time; more specific the time until the second coming of Christ. An existential dimension was added by St Augustine, dividing human existence into existence in the City of God, symbolising religious people, and the city of man, indicating people living in the 'secular' reality in the absence of the guidance of God. The result was that those people living without Christianity was considered 'secular'. References to the secular now included temporal as well as existential meanings.

The concept secular became part of theological language during the Middle Ages. Priests in the Roman Catholic tradition were able to select an affiliation with a religious order as opposed to priests who were able to select a life in the world without any attachment to a specific order. A further meaning of the word saeculum during the Middle Ages, was to refer to the estrangement of church property - 'making worldly' when selling properties belonging to the church (Casanova 2011:56). The apparent understanding of saeculum as referring to temporal matters was later extended so that saeculum also referred to two distinct worlds, that of the religious, sacred and spiritual as opposed to the secular, profane and temporal (Casanova 2011:56).

The term secular also attained an ontological dimension. The concept secular was perceived as an elaboration on the ancient idea by Plato that mankind should engage in higher activities elevated 
above the (secular) world which is by its very nature corrupt and sinful (Calhoun et al. 2011:12). The concept 'secular' eventually referred to the temporal and spacial and existential limitations of human existence. Over time a qualitative value was added. The inferior secular world stood opposed to the superior sacred world. This differentiation also played out in the separation of transcendence and immanence.

According to Casanova (2011:55) two distinct meanings of the concept of the secular developed. Secular could refer to a residual category. Secular then referred to the residual remains after religion disappeared from society. The secular could however also refer to a reality replacing religion. Religion is then perceived as an unnecessary addition or superstructure covering the secular. This description is what Taylor refers to as 'subtraction stories' (Taylor 2007: $29,531)$.

Casanova (2011:54) differentiates between secular, secularism and secularisation. The secular is a fairly modern category according to Casanova (2011:54), resembling a reconstructed reality different from the religious. The secular functions differently in varying contexts and therefore Casanova suggests we talk of 'secularities' which function parallel to different spiritualities (Casanova 2011:54). During previous periods the secular was not considered a field worthy of independent research. Only that which was concerned religious was researched (Casanova 2011:54).

It is clear that the concept of the secular developed within a Euro-Western-Christian paradigm. Dobbelaere (2011:611) convincingly identifies examples of the secular outside the Euro-Western-Christian context. In the Muslim world (i.e. Turkey and North Africa) similar processes of secularisation are evident. Hans Joas and Klaus Wiegandt (2009) indicated how secularisation can be found amongst all world religions. Talk about the secular betrays a Western world view (cf. Casanova 2011). A distinction between religious and nonreligious is only evident in a Western frame of thought. In Africa and Eastern world views, Casanova (2011:55) indicates, the concept of the secular has not always been present. This is due to the fact that there is no separation between that which is considered religious and everyday life. A separation between the secular and the sacred is incomprehensible within such contexts. The concept of separated spheres of the sacred and the secular became acceptable worldwide due to the processes of globalisation and colonialisation (Casanova 2011:54). Dobbelaere (2011:606) refers to this phenomenon as 'compartmentalization'.

A distinction between secular, secularism and secularisation demands an explanation of the related terms. Secularism can be described as a world view or ideology which can take on many different forms (Casanova (2011:54), such as the differentiation between state and religion, which Huber (1999:44) also emphasises. Secularism can also refer to the differentiation between science and philosophy (theology) and between law and morality (Casanova 2011:55).
Secularisation however, has varied meanings. Secularisation can refer to individual piety, or to the demise of religion in society at large (Dobbelaere 2011:599). Dobbelaere (2011:600) identifies not only a macro or micro level but also a meso level where secularisation has an effect. Dobbelaere (2011) defines secularisation as:

$[A]$ process by which overarching and transcendent religious systems of old are confined in modern functionally differentiated societies to a subsystem alongside other subsystems, losing in this process their overarching claims over these other subsystems. (p. 600)

Dobbelaere emphasises the aspect of secularisation as referring to the loss of control by religious institutions over other subsystems like polity, economy, family, education and law. Secularisation changes the relationship between the existing subsystems. The result of secularisation is that religious domination over other subsystems disappear. That which is considered as religious is now equal to or inferior to other subsystems. Huber (1999:51) confirms this understanding.

A different perspective is presented by Bruce. Secularisation is a process resulting from social and economic influence (Bruce 1996:26). In this regard also compare King (2009:31). The analysis of religion from a social perspective provided by Durkheim and Weber contributed to the understanding of secularisation (Bruce 1996:37). Materialism and mass production of commodities brought about changes in social structures, eventually leading to secularisation. For Bruce (1996:32, 2002:3) secularisation exhibits three characteristics: (1) the importance of religious institutions in society is on the decline, (2) the social standing of religion is on the decline, and (3) people are considered to be less religious. Bruce foresees that the gradual decline of religious affiliation will cause that religious people will eventually become a small minority in society (King 2009:31).

Secularisation describes a process characterising the modern era (Casanova 2011:54; Huber 1999:51). Secularisation refers to the changes being made in the relationship between the religious and the secular institutional spheres. At the core of the process of secularisation is the theory of evolutionary movement, from a primitive sacred to a modern secular (Casanova 2011:54). Religion is perceived as a redundant superstructure to be removed, restoring the secular as the natural order of things (Casanova 2011:56). Casanova (2011:55) indicates that over time two distinct theories of secularisation developed: religion will decline (predicted by Berger, Durkheim and Weber) and that religion will be privatised (proclaimed by Luckmann, Berger and Durkheim). This causes Casanova (2011:55) to define secularisation as 'a process of differentiation and liberation of the secular from the religious.' The result is that the secular is seen as superior to and preceding the religious (Casanova 2011:56).

Secularisation can be categorised into three different categories: 'secularisation as differentiation of the secular spheres from religious institutions, secularisation as decline 
in religious beliefs and practices, and secularisation as marginalization of religion to a privatized sphere' (Casanova 1994:211).

According to Casanova (2011:66) secularism can refer to (1) modern world views and ideologies concerning religion. Secularism becomes an ideology when it contains a theory of religion. Secularism can also refer to (2) the separation or rearrangement of relationships between state and religion; science and theology; law and morality. The purpose of this separation is to create a democratic society where neutrality and equality exist. Secularism would then refer to state policy relegating religion and politics to separate domains (Casanova 2011:69).

Taylor (2007) is unoptimistic about the current state of religion. Secularisation must be understood within the current paradigm. Taylor (2007:542-557) states that this paradigm functions within what he refers to as the 'immanent frame'. The immanent frame is constituted by the cosmic, social and moral spheres. These are all secular and have no immanent transcendence. This results in people living as if God does not exist (cf. Körtner 2006:51). A new paradigm describes the current state of affairs. Now faith in the transcendental no longer is logic or uncontested. Faith in God has become problematic. Those in society who decide to believe, realise their decision to believe is just one choice amongst many. There are those who choose not to believe. Secularity has become the default option (Casanova 2011:58).

It is apparent from this analysis that to speak about secularisation as a process, an assumption is made that something different existed prior to secularisation. Before the secular can set in, the sacred must be present. This assumption indicates that the church did act and believed in a manner different to what is considered secular. Huber's (1999:31) contention is therefore that the church through its very own actions, words and decisions contributed to the success of the process of secularisation.

For Huber the foremost incident of self-secularisation is the church's decision to make moral challenges the main theme of the church. The meeting with the Holy, experiencing the transcendental became a secondary theme. With the multitude of moral orientations in society at offer and the autonomous individual able to select their own orientation, members of society no longer look at the church for spiritual guidance. This causes a disruption in what Huber (1999:19) identifies as a problem in 'spiritual orientation'. This change in focus became apparent in German Protestant churches when in sermons the emphasis no longer fell on proclaiming the incarnation of God in Jesus, but the emphasis fell on being a good neighbour to fellow human beings (Huber 1999:32). This led to a reduction of the message of the church. It also had the consequence of setting Christianity on an equal level with all other religions (and even secular orientations) which are also proclaiming an ethics of neighbourly love. The Christian message became relative in terms of other religions and so contributed to the secularisation of the church.
Huber is speaking from a Western European context and in particular on behalf of the Protestant community in Germany. The research undertaken here intends to test Huber's theory in regard to the Protestant community in South Africa.

\section{Challenges presented by self-secularisation}

Many authors from different contexts from all over the world have attempted to analyse, describe, diagnose and present prognoses and solutions for the state in which the church finds itself. South African scholars also contributed to this effort. ${ }^{1}$ Schoeman (2014:1 of 10) reminds us that the decline in church membership is an international phenomenon. The South African Protestant community is also concerned about the decline in church membership (Heyns 2015). Christo van der Merwe (2014:1 of 13), to whom this article is dedicated, also reminds us of the reality of the survival of the church in the face of changing paradigms. After scrutinising different theories as to the effect of self-secularisation in South African churches, the following instances of self-secularisation can be identified.

\section{Theological jargon}

Ulrich Körtner (2006:24) indicates that according to his analysis the church has become deprived of faith language. This element has three facets to it: Ignorance of theological expressions, too high sophisticated language and too low 'empty' language.

\section{Ignorance}

Ordinary church folk, according to Körtner (2006:25), have forgotten the basic theological concepts and their meaning. Basic theological terminology such as incarnation, salvation, redemption, resurrection, epiphany, pneumatology and eschatology has become redundant. Since the meaning of the concepts has been forgotten by the lay church members, the terminology is only used by the ordained few. Even amongst clergy the terminology is utilised filled with different meanings. It may even be the case, according to Körtner (2006:24), that the church coming from the privileged position of a national church, assumes that everybody knows what the terminology means as the church has been part of the community for so long. Even amongst clergy there seems to be not a strong consensus as to how the terminology should be applied. This contributes to confusion within the church. Part of the confusion, Körtner (2006:25) indicates, is that due to ignorance invalid and strange connections with terminology appear. As an example the effort to combine the concept of the hope of resurrection with the Eastern concept of reincarnation is cited by Körtner.

The youth members of the church no longer undergo a thorough process of catechism. This is the forum where

1.Compare in this regard the following statements: 'Formal churches lose their flock'(2012). Christian nominality in South Africa may be as high as $75 \%$, (see flock'(2012). Christian nominality in South Africa may be as high as 75\%, (see
Kritzinger 1994); Church membership on decline in Dutch Reformed and Roman Kritzinger 1994); Church membership on
Catholic Church (see Chipkin \& Leatt n.d.). 
theological terminology is explained. With fewer youth members, the church no longer deems it necessary to replicate a scholastic mode of education. In desperateness to maintain church membership amongst youth the church resolves to entertaining the youth instead of training and teaching them.

\section{Too high}

Sophisticated theological terminology with which ordinary lay church folk is no longer familiar, confuses and drives people from the church. This is part of the heritage of the Enlightenment. Scientific language reflects control, knowledge and complexity. By being able to name phenomena, to analyse and discuss these, the impression is created that a matter has been fully analysed, turned inside out and that everything there is to know about something, has been identified. By knowing something, one is able to control and manipulate its application and implication.

Scientific language is the result of rationalisation, the prized endeavour of the enlightenment. See below ('Rationalisation') a discussion of the role of rationalisation in the selfsecularisation process.

Clergy over centuries discussed theological constructs created through rational engagement with events and experiences recorded by believers. The fact that so many theological interpretations and denominations exist, rather confuses and creates lethargy and indifference amongst believers. 'If those who are supposed to know cannot agree on what it is that we should believe, how are we to know?' (Körtner 2006:26)

\section{Too low}

In an attempt to clarify and simplify theological jargon, the church has ended up with an empty basket. Körtner $(2006: 26,85)$ indicates how the church through its inability to substantiate faith ended with the degradation of theological language. Christianity as a whole did not manage to express its message in relevant language for a new generation living in new contexts. All language about God has become irrelevant (Körtner 2006:26).

The symptoms of this problem of 'too low' (irrelevance of theological statements) language are most apparent in sermons. Clergy are at times also uncertain of the theological meaning of terminology, are too lazy to study the meaning, and also realise the ignorance of the audience when it comes to knowing the content of the terminology; they rely on good story telling and creative imagery in their sermons to carry the message. The content ends up not being theological but filled with entertaining images and stories. The language and concepts are un-theological and the messages become artificial. The simplistic explanations provided for theological concepts rather irritate and estrange.

\section{Mass media and infotainment}

Part of the problem with the language of the church is that the message the church is preaching no longer has the function of the formation of faith, but much rather has the function to entertain. Körtner (2006:12) refers to this phenomenon as 'religious infotainment'. The church moulds its message into a format that is acceptable and familiar to society. By taking part in televised church services and communicating through social media, the church presents itself as being part of the world, modern enough to be relevant. What in fact happens is that the message is lost and only the medium impresses. This 'virtualisation of Christianity' leads to a situation which Körtner (2006:13) describes as 'the medium is the message'. The focus is no longer on the content but on the presentation.

This is not only true of Protestant churches, and not only in Germany. In the South African context many Pentecostal churches have refined the 'medium' of communication to such an extent that it has become difficult to distinguish between when the church is presenting a message and when it is just another (secular) social event. This trend is followed by many Protestant churches as well. This modus operandi of the church contributes to the in-distinguishability of the church from the world.

\section{Rationalisation}

Ever since the Reformation, expression of faith was encapsulated by rational thinking. For the church this process however started much earlier. In an effort to precisely articulate elements of doctrine the church ended up with synods discussing the precise wording of doctrine. This as a rational process determined the attitude with which the doctrine was formulated and the content revered as expressions of the holy.

Max Weber has since the middle of the 19th century identified the destructive process of rationalisation. Weber differentiates between different classes in society. One of the strata in society he identifies is the intellectuals (1966:124, [1958] 2003:35). The intellectuals tend to seek through rational ways meaning in reality (Weber 1966:125). Rationalism suppresses the belief in magic and results in a world disenchanted (Weber 1966:125, [1958] 2003:105). Reality becomes demystified through the process of rationalisation. That which is considered mystery is explained through rational ways, leaving the world devoid of mystery, secrets and gods. Weber called this the 'worldfleeing intellectualist religion' (1966:125). Rationalism leaves no room for the transcendental to operate in the immanent reality. Every mysterious event has a logical and rational explanation. Empirical phenomena receive a clearly defined meaning. Religion has become obsolete.

In as far as the church over the centuries was guilty of practising 'intellectual religion', the church contributed to the de-mystification of the world. Körtner (2006:54) refers to this as the church's ability to keep God veiled and invisible to the world. The theodizee question contributed to the fact that society is convinced that God does not exist, is dead or if he exists, is powerless (Körtner 2006:55). The church's inability to explain the absence of God, in spite of the revelation by God, caused theology to be a stillborn infant. To rectify this 
impasse the church created what Körtner (2006:68) refers to as a 'negative theology'. It was only possible to talk about God in terms of what he is not. The impasse also led to a situation whereby clergy (human talk) of God became misleading (Körtner 2006:65). The world has truly become de-mystified.

Weber believes that Protestantism is more prone to economic rationalism ([1958] 2003:40). Weber suggests that Protestants promote rationalism as a means to find prosperity. Protestants have interpreted the abundance of wealth and prosperity as an indication of divine blessing and grace (Weber 1966:108, 148). The love for worldly possessions evident among Protestants, will gradually distract attention from religion (Weber [1958] 2003:42) and lead to secularisation (Weber [1958] 2003:40). Weber concludes that Calvinism is the seedbed for a capitalistic economy ([1958] 2003:43). Thus, through rationalism and materialism Protestants will bring about secularisation which will lead to the demise of religion and the church.

The church can easily become a victim of the rationalisation process. To explain the demise of the church in current times the church can rationalise the problem and project the causes of the dilemma to the individualisation and autonomy of society. The effect of secularisation can be blamed for the empty pews. The multi-religious society can be seen as the reason for the church not to grow. These factors need to be taken into account, but the church cannot deny its own contribution to the dilemma in which it finds itself.

\section{Emotionalism}

In reaction to the Enlightenment many scholars tried to introduce emotion as part of the awareness in religion. Already during the 18th century, Schleiermacher ([1899] 1991: 60) indicated the existence of a different mode to encounter reality. Through feeling (more precisely intuition), reality can be experienced. For Schleiermacher ([1830] 1960:23) the most basic of all human feelings is the feeling of dependence. This is the origin of religion. Since Schleiermacher, the importance of feeling within the religious experience spread, resulting in the extreme of pietism on the one hand and experience of the transcendental in the mode Rudolf Otto (1932) professed on the other hand. The transcendental can be experienced and felt through more than sensory experience. It is possible to experience God through feeling or an awareness of fear and fascination (tremendum and fascinans) (Otto 1932:14, 43).

Faith as psychologically based experience is currently the main characteristic of the spirituality of the church. Feeling, experiencing and sensing have become normative ways of experiencing faith. The rational spirituality characteristic of the Enlightenment, no longer seems to be constitutive of current faith expressions. The churches of the Reformation still seem to be strongly rationalistic in orientation. When the pendulum in reaction swings too far to the one side, the emotional spirituality is overemphasised. Only that which is felt becomes valid and the normative expression of faith. Church communication is reduced to prescribing good manners and encouraging positive feelings. For those who are still rationally inclined in their faith experiences, there is no place in the church. The church has become based on and substantiated by emotion.

The dilemma here is not the presence of emotion. It is merely a matter of balance. If the rational substantiation of faith is neglected, faith becomes just another emotion, flickering in the wind of change. As mention of the danger of rationalisation of faith has already been made, the point is to notice the balance between rational and emotional substantiation of faith.

\section{Civil religion}

Christianity's close connection with Western society brought the assumption that everybody who is part of Western civilization is automatically part of Christianity. Culture and religion were equated so that the borders of a nation formed the natural boundaries of the particular version of Christianity found within that cultural group. This phenomenon became known as 'civil religion'. Part of the implication is that civil society is a homogenous group (very often) intolerant of other religious affiliations (Huber 1999:19).

From a sociological perspective some insights into the definition of civil religion can be gained. The origin of the concept of civil society lies for Huber (1999:270) in the Aristotelian image of the polis as open society. The concept of civil religion refers to the situation where conversion to a particular religion is ethnically based. The spreading of a religion occurs along the lines of language and culture (Bruce 1996:96), resulting in what Bruce calls 'nominal conversion'. The result is that belonging to a particular culture implies belonging to a particular belief. Religion has become guardian and defender of ethnic identity. Civil religion can be described as a remnant of a society trying to restore the status and conditions of a previous era, where religion influenced decisions made in society. A society under thread of secularisation, can either adapt to new conditions or attempt to restore the familiar past. Civil religion can be described as an example of the latter.

Ronald Johnstone ([1975] 2004:153) adds a sociological perspective to the understanding of civil religion. Johnstone indicates that a section of society can be convinced that the foundation of society and its progress through history is part of a larger, divine plan. Society as a structure is then perceived from a transcendental dimension. Identity and a sense of belonging is received from being part of the divinely elected nation. Religion is integrated in social life. Johnstone ([1975] 2004:154) indicates how Williams refers to this as 'societal religion'. Religion then has the function of maintaining the democratic nature of society and integrating members of society into one whole.

The borders between the worldly (secular or profane) and the churchly (divine or sacred) have been blurred. The concerns and values of the nation have become the concerns 
and values of the religious group (church). The church is therefore reduced to a defender and protector of national interest. This especially is the case when Christianity becomes the state religion.

South Africa has a constitution priding itself in religious tolerance and freedom (South Africa 1996: see ch. 2, ss. $9,15 \& 31$ ). Although equality of religious affiliation is a value professed by the Constitution, there seems to exist a discrepancy when compared to reality. Gerald West (2007:22) is convinced that the current government although guaranteeing religious freedom favours one particular religion, namely Christianity. This is evident, judged by the many allusions to Christian themes made in speeches by politicians.

The church is as much a victim as a protagonist in this matter. In a society where it is expected of the church to participate in political and community decisions the church is assigned the role of protector of society. The church has for many years played an active role in opposing and fighting apartheid in South Africa (Hastings 1991:166). If the church cherishes and covets such a position of power, it neglects its task of preaching the gospel. Huber's (1999:267) contention is that the church rather takes on the role of 'intermediary institution'.

The implication is that the church cannot but exist within society, being part of the local context. As part of society the church as institution confronts other powers within society in a normative and ethical fashion (Huber 1999:268). The church and not the media should determine the ethics of society. The problem, however, Huber (1999:269) identifies is that the church should acknowledge the fact that in (most) current societies the church as expression of Christianity is but only one amongst many different religions (cf. below the issue of pluralism). The church should therefore take its place in the 'triad' of state, religion and society (Huber 1999:269). The church is not to be seen as contra-society nor integrated within society. Instead Huber (1999:269) suggests that the church should be aware of its unique task and message it takes in the position of an intermediary. The church intermediates between the individual and the society, and the individual in relation to God. In this way the church becomes the 'intermediate institution'.

\section{Pluralistic society}

A new paradigm permits new modes of understanding. A modernistic paradigm allows only one truth to exist. The postmodern paradigm allows for multiple truths to co-exist simultaneously, creating a plethora of truths. Pluralism characterises our existence (cf. Huber 1999:19). A pluralistic society denies homogeneity and acknowledges plurality (Huber 1999:282).

When the church in such a pluralistic society becomes convinced of its own ordinariness and generality, the message and mere existence of the church is relativised.
The church starts understanding itself as just one voice amongst many. These voices do not sing in harmony where different intonations can be distinguished. Rather all sound the same, making any religion just as good as the next. If the church starts believing this and starts creating its identity around this, the church contributes to its own condition of being irrelevant to society. It does not imply that the church should claim superiority but rather emphasise uniqueness. Huber (1999:282) indicates that existence within a pluralistic society requires mutual respect and an openness to realise the borders of plurality. Only when religions acknowledge one another can they peacefully exist in the open without retracting into privacy.

The opposite of existing in a pluralistic society would be to confine oneself to the restrictions of fundamentalism with a claim on the sole possession of the truth. Huber (1999:283) suggests that in order for the church to remain relevant in society it cannot but exist in society, being part of society, amongst other religions. Being part of the religious community will keep the church relevant and in touch with a religious orientation (Huber 1999:19).

\section{Commercialisation of the church}

It has already been indicated earlier in this discussion how Weber identified the Protestant community's tendency to contribute to the expansion of capitalism. Today the question needs to be asked how far the church has contributed to the commercialisation of the church.

In a business-orientated society everything is for sale. In order to gain financially under the guise of serving the community, the church commercialised its product. The message is packaged in variable forms: books, CD, DVD, live streaming. Training material with study guides and programmes are put up for sale. In order to be successful the church has become an expert marketer and presenter. The message of the church has become a sought after commodity available in many forms.

The church itself started creating successful communities that can be replicated in different vicinities. The franchising church has arrived. In an open-market society the church with the most attractive advertising strategy attracts the most attention. This diverts the attention away from the content the church is supposed to convey and the emphasis is placed on the form of the presentation. The medium has indeed become the message (Körtner 2006:13).

In honest attempts to assist the church in managing its own affairs, consultants seem to introduce business principles to be applied in the church. Leadership is reduced to management; faith in providence is replaced with strategic planning; the gifts (charismata) are reduced to advanced skills; spontaneous koinonia is reduced to organised interaction. The church is managed like a business. This leads to a situation where the church is no longer differentiated from the ordinary (secular) institutions in society. 


\section{Lack of moral integrity}

The shift in focus away from God incarnated in Jesus to the ethical responsibility towards the other identified by Huber has already been indicated. This creates a dual problem: the shift in focus and also incongruence. The church emphasises its ethical responsibility and teaches neighbourly love at the expense of the message of salvation through Jesus Christ. The church ends up teaching human interdependence which is in opposition to the Reformation message of sola fidei, sola scriptura, sola gratia. God alone saves and through his love humans learn what love is. Now the church is teaching humans to care for one another, forgetting the place of God in the equation. Compare in this regard Körtner's (2006:51) statement that the church exists in a time of religion without God.

Faith-based acts of charity have become humanism. Körtner (2006:59) refers to this phenomenon as a religion focused on an earthly love. There is a movement away from a belief in a theistic God to a belief in the effect of love. The need of the other is emphasised. The buzzwords 'human rights and dignity' have created a new opportunity for a crusade for the church. In an attempt to rid the whole world of evil, injustice and oppression the church was so taken up by its own attempts that the message of salvation through faith in Jesus Christ has been reduced to a slogan which all Christians will still agree on, but not all live by according to the implication thereof. God has been replaced by love (Körtner 2006:60).

There is a difference between contextualisation and authentic and relevant contextualisation (cf. Hesselgrave \& Rommen 1989:199). To have the message of the gospel is to bring the text to the world. Christianity remains a religion of the Word (Körtner 2006:81). The text however needs to address the needs of the context. ${ }^{2}$ The interpretation of the text includes understanding, explanation and application (Gadamer [1975] 2004). When the primacy of the context however determines the relevance of the message the balance shifts to the context. When the text is introduced without taking the context into account, the text shows no relevance. A balance is required between the context and text to determine the communicative process in equal measure.

Contextualisation refers to the successful transfer of the message of the gospel in such a way that it is meaningful to the local context (Hesselgrave \& Rommen 1989:199). The measure for authenticity is that the message is faithful to God's revelation in his Word. This message should be put meaningfully into a particular cultural context (1989:200). Incongruence emerges when the message intended does not reach the audience in a meaningful way. When the meaning intended is different to the meaning received, incongruence is the result. The church has indeed the ability to veil God.
Love for humans becomes the inauthentic transfer of the gospel message as a result of focusing only on the contextual need. The text (gospel) requires love for God and the neighbour. Authentic contextualisation would require proclaiming the whole message.

These are several instances of where the church (at times unintentionally) tends to play into the hand of secularisation. Continuing on this trajectory the church may become more and more irrelevant, to the border of extinction. As indicated earlier, there probably are internal as well as external factors contributing to the condition in which the church currently finds itself. As to the external factors there is not much the church can do except to accept the change in paradigm and its consequences. As to the internal elements from within the church, the church will have to be aware of its own selfdestructive behaviour and change it.

\section{What can the church do?}

Up to this point we have stated it clearly that all Protestant churches all over the world are experiencing a decline in the number of its members. There are several reasons for this decline. These reasons can be divided into external and internal categories. The external factors are not necessarily our concern now. Huber has labelled one of the internal factors self-secularisation. After a brief description of what is understood by secularisation and self-secularisation, several instances of self-secularisation in the South African context have been discussed. This research will be impotent if it does not address the correction or at least provide suggestions as to how to rectify the self-secularisation process.

Huber's (1999:32) suggestion as to what the church could do under the current conditions is first of all to be honest and be self-critical. The church cannot turn a blind eye to the fact that it is losing members and income. The church will also need to be critical about its own acts, words and decisions that contribute to the effect of people leaving the church. After acknowledging the fact that the church has lost focus, Huber suggests the church should engage in a process of spiritual orientation (1999:32). This spiritual orientation includes the following below.

\section{The issues of faith need to be put on the table again}

The first step Huber (1999:235) suggests the church to take is to pay attention to its own message. The church needs to depend not on its own abilities, nor management principles, but on God who through his Spirit guides and governs the church. The solution to the dilemma in which the church is, is a spiritual dilemma only God can solve. The structure of the church, the vessel by which the message is transmitted cannot heal itself. The church needs to become aware of the content of its message and to allow God through his Spirit to act and heal. The church will need to take heed of what Schleiermacher ([1830] 1960:23) has already pointed out, that at the root of religion (in this case Christianity) lies a feeling 
of dependence. The church must realise its dependence on God. The church is preaching the message of salvation only in Christ. Now the church must believe its own message and seek redemption from God.

The most important corrective required is what Huber (1999:264) calls a change in orientation. The issues of faith, the essence of the message of the church needs to be rediscovered. Huber (1999:264) emphasises that the orientation includes an emphasis on the Crucifixion and Resurrection of Jesus Christ. This is the essence of being church. Attention to this credo only indicates the beginning of a fresh start.

Körtner $(2006: 81,107)$ formulates the solution differently. To him the church needs to engage in a Word-of-God theology. For the Christian faith and message the Word of God remains essential. The packaging of the message can easily become the focus ending with the medium that becomes the message. The Word (message) must remain central. Körtner (2006:71) warns the church not to confuse the message with false alternatives. These false alternatives arise from what Körtner (2006:81) calls the 'culture theological concepts'. Issues important to a particular culture become important issues to the church serving such a community. Such processes only contribute to self-secularisation.

The South African Protestant community will need to carefully filter its topics that currently determine the agendas of the church. Are these topics remnants of cultural concerns or truly elements that the Word of God requires the church to be concerned about? Of course the church needs to address the contexts it exists in, but then the conversation must be determined by the Word of God. As Körtner (2006:71) indicated only recently, theologians have emerged daring to address the current context of globalisation, ecology, poverty and discrimination. The context and the text are necessary in order for the church to make a valid and relevant contribution to human existence. This is what I would like to call theology with integrity; the text (word of God) as well as the context is dealt with in a responsible manner.

In the end, the beginning of the restoration of the church is a process parallel to that of the Reformation. The church needs to return to the sources (ad fontes). The Word only (sola scriptura) is where wisdom, healing and growth for the church lie. This process of re-introducing spiritual matters of faith to society is referred to by some (cf. Berger 1999) as re-sacralisation, re-introducing the transcendence in the immanence.

\section{New expressions of responsibility}

Christians need to find a new expression of taking responsibility for the other (loving thy neighbour in a new context).

Huber (1999:320) sees the future of the church as establishing a culture of help in society. Under a paradigm supportive of pluralism and individualisation concern for the other has become a redundant virtue. Pluralism brings the 'other' into the vicinity of the 'own'. Due to the threat this may cause to the 'own', aversion and intolerance are the result. Several instances of xenophobic attacks in South Africa during February 2015 are examples from Southern Africa. Individualisation puts the concerns and interests of the individual at the centre. The independent individual is in competition with the neighbour. Natural selection (survival of the fittest) causes a competition for limited resources (i.e. food, water, career opportunities).

This condition makes charity and neighbourly love the exceptions. In this scenario the church must present an alternative community with alternative values. Huber (1999:320) indicates with the 'culture of help', the church needs to act upon the needs of those in society who will not survive without the help of others. As model for Christian charity Jesus is portrayed as helping those in need. Huber (1999:320) however, emphasises that help towards others has the intention of helping others to help themselves. The church must help others to become independent and autonomous. The whole of society needs to engage in action to take care of those in need. A holistic approach is part of the transformation toward a culture of help.

It is clear that with neighbourly love Huber does not imply humanistic charity. Against this phenomenon he has already warned (Huber 1999:19). Charity cannot become the central focus of the church. Neighbourly love is theologically grounded. Based on God's love for all humans, Christians are encouraged to love their fellow human beings.

It needs to be kept in mind that Huber is speaking from a European context. Expressing neighbourly love in such a context might only entail making resources accessible to others. In an African context the situation is more complex. In a context with insufficient resources, the task is no longer only to grant accessibility, but to create criteria for equal and fair distribution of limited resources. This newly assigned task is part of the way in which the church needs to find new ways of expressing neighbourly love.

\section{Christian faith becoming relevant for social issues and taking on social form}

Although Huber has warned against the danger of civil religion, the social responsibility of the church cannot be denied (Huber 1999:305). The way in which the church engages in social issues must be sincere and with integrity. Sincerity refers to addressing the issue at hand without seeking benefit for oneself or advancing one's own interest. Huber (1999:305) indicates how the church for a very long time took on the function of protector of values in society. Protecting society can give the church command and control over society. The church's search for power then becomes the goal. In a pluralistic society the church is now only but one voice amongst many dictating values. Sincere concern for the well-being of society provides the church with credibility. 
Integrity requires from the church to address social issues and simultaneously maintain one's own convictions. Huber (1999:293) indicates that one of the main social responsibilities of the church is education. In the conviction that education is part of the church's responsibilities, Huber (1999:294) builds on the church reformer, Melanchton's, understanding. For Melanchton education is incomplete when it does not take place within the dimension of faith and is filled with religious themes. The connection between the social engagement through education and faith formation is an indication of the church maintaining its integrity.

In a pluralistic society the church is however not the only institution concerned with education. The church merely takes on the role of an intermediary institution (Huber 1999:267) by not replacing the state's efforts at education. All religions may understand their social responsibility in terms of providing education. Huber (1999:298) suggests that the church should focus on religious study in order to instil the meaning of religion as an essential dimension of human existence. Once the meaning of religion for cultural existence has been established, knowledge of the Christian tradition can be addressed. With these two phases of religious education Huber suggests that a general knowledge of religious phenomena within a pluralistic society opens up society to tolerance through knowledge of the other.

One of the elements of religion is ethics. By instilling a religious orientation in society, a value-laden society is created. Different values will apply simultaneously within a pluralistic society. A society with a spiritual orientation counters the process and effect of secularisation. By participating in setting up this spiritual orientation, the church is countering self-secularisation. Religions that work together address social issues. Inter-religious co-operation is to the benefit of society.

\section{Conclusion}

The first step towards restoring the credibility of the church is acknowledging that which is not correct. To be self-critical is crucial. This is especially difficult for a church that lives under the illusion that it is infallible. Everything the church says and does is supposed to be divinely inspired. How can the church then be wrong? The church must be aware of deceiving itself. The church can (and has) been deceiving society with inauthentic messages. Once the church is willing to critically look at itself, it must be willing and honest enough to see the wrong and inefficiency of its words, actions and decisions. In this regard the church must be willing to be a prophet to itself, hear the chastisement and rebuke.

After repentance the church needs again to discover the $\mathrm{s}(\mathrm{S})$ ource of its message. This is what Huber and Körtner have addressed. Huber's call for a 'spiritual orientation' and Körtner's call for a Word-of-God theology indicates the direction the church needs to go in order to travel on the road to restoration. This is only the medicine not the cure. The medicine needs to be taken in order for the cure to set in. This will require extreme courage by the church, courage to be self-critical, courage to acknowledge the mistakes and courage to engage on a route to correct the wrong. Since the church is in this instance the culprit (self-secularisation), the blame for the condition in which the church finds itself cannot be blamed on anybody or anything. The church needs to stop turning itself into a secularised institution.

Huber, as well as Körtner make it clear that the restoration process is not only an intellectual process. Huber's spiritual orientation also implies an orientation in existence and action. The church needs to see itself as servant of society and act according to this identity. The church needs to find new ways of expressions of love towards others. In this way the church is inviting the sacred to reside among the secular.

\section{Acknowledgements Competing interests}

The authors declare that they have no financial or personal relationships which may have inappropriately influenced them in writing this article.

\section{References}

Berger, P.L. (ed.), 1999, The desecularization of the world, Eerdmans Publishing, Grand Rapids, MI.

Beyers, J., 2014, 'The church and the secular: The effect of the post-secular on Christianity', HTS Teologiese Studies/Theological Studies 70(1), Art. \#2605, 12 pages, http://dx.doi.org/10.4102/hts.v70i1.2605

Bruce, S., 1996, Religion in the modern world: From cathedrals to cults, Oxford University Press, Oxford.

Bruce, S., 2002, God is dead: Secularization in the West, Blackwell Publishers, Oxford.

Calhoun, C., Juergensmeyer, M. \& Van Antwerpen, J., 2011, Rethinking secularism, Oxford University Press, Oxford.

Casanova, J., 1994, Public religions in the modern world, University of Chicago Press, Chicago, IL.

Casanova, J., 2011, 'The secular, secularizations, secularisms', in C. Calhoun, M. Juergensmeyer \& J. van Antwerpen (eds.), Rethinking secularism, pp. 54-74, Oxford University Press, Oxford.

Chipkin, I. \& Leatt, A. n.d., 'R.eligion and revival in post-Apartheid South Africa', viewed 18 February 2015, from http://www.hsf.org.za/resource-centre/focus/ focus-62.pdf

Dobbelaere, K., 2011, 'The meaning and scope of secularization', in P.B. Clarke (ed.), The Oxford handbook of the sociology of religion, pp. 599-615, Oxford University Press, Oxford.

Durkheim, E., [1912] 2008, The elementary forms of religious life, transl. C. Cosman, Oxford University Press, Oxford.

'Formal churches lose their flock', 2012, City Press, viewed 18 February 2015, from http://www.news24.com/Archives/City-Press/Formal-churches-lose-theirflocks-20150429

Gadamer, H-G., [1975] 2004, Truth and method, 2nd rev. edn., transl. J. Weinsheimer \& D.G. Marshall, Continuum, London.

Hastings, A., 1991, Politics and religion in Southern Africa, in G. Moyser (ed.), Politics and religion in the modern world, pp. 162-188, Routledge, London.

Hesselgrave, D.J. \& Rommen, E., 1989, Contextualization: Meanings, methods and models, Baker Book House, Grand Rapids,MI.

Heyns, F., 2015, 'Die Christendom, ateïsme en die rol van die kerk', Kerkbode, Deel 194(2), 12-13.

Huber, W., 1999, Kirche in der Zeitenwende: Gesellschaftlicher Wandel und Erneuerung der Kirche, Gütersloher Verlag, Gütersloh.

Joas, H. \& Wiegandt, K., (eds.), 2009, Secularization and world religions, Liverpool University Press, Liverpool.

Johnstone, R.L., [1975] 2004, Religion in society: A sociology of religion, 7th edn., Pearson Education, n.p., NJ.

King, M., 2009, Postsecularism: The hidden challenge of extremism, James Clark \& Co., Cambridge.

Körtner, U.H.J., 2006, Wiederkehr der Religion? Das Christentum zwischen neuer Spiritualität und Gottesvergessenheit, Gütersloher Verlagshaus, Gütersloh.

Kritzinger, J.J., 1994, 'Christians in South Africa: The statistical picture', HTS Teologiese Studies/Theological Studies 50(3), 610-618. 
Otto, R., 1932, Das Heilige: Über das Irrationale in der Idee des Göttlichen und sein Verhältnis zum Rationalen, C.H. Beck'sche Verlagsbuchhandlung, München.

Schleiermacher, F., [1830] 1960, Der christliche Glaube, vol. I, ed. M. Redeker, De Gruyter, Berlin.

Schleiermacher, F., [1899] 1991, Über die Religion. Reden an die Gebildeten unter ihren Verächtern, 7th Aufl., ed. Rudolf Otto, Vandenhoeck \& Ruprecht, Göttingen.

Schoeman, W.J., 2014, 'Agter die syfers is gelowiges, gemeentes en die kerk, 'n praktiese teologiese refleksie oor lidmaatskap', HTS Teologiese Studies/Theological Studies 70(1), Art. \#2677, 10 pages. http://dx.doi.org/10.4102/hts.v70i1.2677

South Africa, 1996, Constitution of the Republic of South Africa 1996, viewed 12 October 2015, from http://www.gov.za/documents/constitution/chapter-2-billrights\#31
Taylor, C., 2007, A secular age, Harvard University Press, Cambridge.

Van der Merwe, J.C., 2014, "n Narratief vir kerk-wees vandag', HTS Teologiese Studies/ Theological Studies 70(1), Art. \#2699, 13 pages. http://dx.doi.org/10.4102/hts. v70i1.2699

Weber, M., [1958] 2003, The Protestant ethic and the spirit of capitalism, transl. T. Parsons, Charles Scribner's Sons, New York, NY.

Weber, M., 1966, The sociology of religion, transl. E. Fischoff, Methuen \& Co., London.

West, G.O., 2007, 'The ANC's deployment of religion in nation building: From Thabo Mbeki, to "RDP of the soul" to Jacob Zuma', viewed 10 July 2014, from http://
www.umkn-dsp01.unisa.ac.za/xmlui/bitstream/handle/10500/4310/West. pdf?sequence=1 